\title{
A weight loss protocol and owners participation in the treatment of canine obesity
}

\author{
Um protocolo de perda de peso e a participação dos proprietários no tratamento da obesidade canina
}

\author{
Aulus Cavalieri Carciofi ${ }^{1}$ Karina Nogueira Venturelli Gonçalves ${ }^{2}$ Ricardo Souza Vasconcellos $^{2}$ \\ Rodrigo Sousa Bazolli² Márcio Antonio Brunetto² ${ }^{2}$ Flávio Prada ${ }^{3}$
}

\begin{abstract}
The success of a weight loss program for pets depends on the owners collaboration. Their compliance is fundamental in establishing the correct food management. The objective of this study was to compare the effectiveness of a weight loss program in two groups of dogs, one maintained under experimental conditions and the other with their owners. The same hypocaloric food was used to feed all animals, the amount being restricted to $60 \%$ of the estimated maintenance energy requirement for a $15 \%$ reduction of the present body weight of the dog. The animals were followed during 90 days. A standard questionnaire was used to study the owners' perception of obesity and its treatment. The protocol and the diet were found to be effective. The control dogs had an average weight loss of $1.39 \%$ per week. Dogs with owners lost on average $0.75 \%$ of their body weight per week, a statistically lower result $(P<0.05)$, suggesting that the owners did not follow the treatment closely. The owners were clearly satisfied with the results that were obtained, even with this modest weight loss. The questionnaires were shown to be an important tool in determining the causes of canine obesity, as well as in the follow-up of the treatment.
\end{abstract}

Key words: dogs, obesity, treatment, diet.

\section{RESUMO}

O sucesso de um programa de perda de peso para animais de estimação depende da colaboração do proprietário. A adesão deste é fundamental para a correta instituição do manejo alimentar do paciente. Este trabalho teve por objetivo comparar a efetividade de um programa de perda de peso em dois grupos de cães, um mantido sob condições experimentais e outro com seus proprietários. Empregou-se a mesma ração hipocalórica para todos os animais. A quantidade fornecida foi restrita a $60 \% \mathrm{da}$ necessidade energética de manutenção estimada para o peso corporal meta, definido como o peso autal reduzido em $15 \%$. Os animais foram acompanhados durante 90 dias. Por meio de um questionário padronizado, estudou-se a percepção dos proprietários quanto à obesidade e seu tratamento. Verificou-se que o protocolo e a dieta empregados foram eficazes. Os animais controle apresentaram uma perda de peso média de 1,39\% por semana. Os cães de proprietário perderam, em média, $0,75 \%$ do peso vivo por semana, resultado estatisticamente menor $(P<0,05)$, o que sugere uma indisponibilidade dos mesmos em cumprir rigorosamente o tratamento. Mesmo com esta perda de peso modesta, foi perceptível a satisfação dos proprietários com os resultados obtidos. O uso de questionários demonstrou ser uma ferramenta importante na investigação das causas e no acompanhamento do tratamento da obesidade canina.

Palavras-chave: cães, obesidade, tratamento, dieta.

\section{INTRODUCTION}

Obesity is presently the most common nutritional disease of developed societies, and it is estimated that 25 to $35 \%$ of dogs are overweight (GRECO, 2002). It is considered to be essentially a nutritional disease, although genetic, social, cultural,

\footnotetext{
${ }^{1}$ Departamento de Clínica e Cirurgia Veterinária (DCCV), Faculdade de Ciências Agrárias e Veterinárias - Universidade Estadual Paulista (FCAV - UNESP). Via de Acesso Prof. Paulo Donato Castellane, s/n. 14884-900, Jaboticabal, SP, Brasil. E-mail: aulus@fcav.unesp.br.

${ }^{2}$ DCCV, FCAV, UNESP, Jaboticabal, São Paulo, Brasil.

${ }^{3}$ Departamento de Clínica Médica(VCM), Faculdade de Medicina Veterinária e Zootecnia, Universidade de São Paulo (FMVZ-USP), São Paulo-SP, Brasil.
} 
metabolic and endocrine factors participate in its genesis (LEWIS et al., 1994; MONTEIRO, 1999).

Owners play a significant role in the weight gain of their animals when they fail in adjusting to individual needs, have difficulty in recognizing the body condition of their dogs; offer snacks ignoring the calories they contain; allowing the food begging behavior and by not providing enough exercises (MARKWELL \& BUTTERWICK, 1994).

Although the beneficial effects of obesity treatment are well known, few veterinarians are willing to treat it. The major challenge is to motivate the obese dog's owner to follow a calorie restriction program. Most people give up because of difficulties found during the treatment, as inadequate weight loss, difficulty in providing exercises or controlling the offer of extra food and other factors (BURKHOLDER \& TOLL 1997).

The objective of this study was to evaluate the effectiveness of a protocol to treat canine obesity and to collect information that would provide a better understanding of the owner's perception of obesity and its treatment.

\section{MATERIAL AND METHODS}

Two experimental groups of obese dogs were formed. A dog with a body score of 5 was considered as obese (EDNEY \& SMITH, 1986). The groups were set up as follows:

Group 1(owners group): included 30 obese dogs (13 spayed females, 12 intact females, 5 intact males), the average age was $6.4 \pm 2.8$ years and the average weight $29.9 \pm 15.9 \mathrm{~kg}$. The dogs were seen during the routine activities of the Hospital Veterinário - FCAV/UNESP, campus de Jaboticabal (HV), between January and August, 2003. The owners spontaneously agreed to follow the therapeutic protocol.

Group 2 (control group): formed by 9 obese dogs (1 intact male, 5 spayed females and 3 intact females). Their average weight was $18.2 \pm 8.4 \mathrm{~kg}$ and ages between 5 and 12 years. It was not possible to determine their precise age because many were donated to the HV when they already were adults. All belonged to FCAV/UNESP. These animals were maintained in one-or two-dog kennels, and had daily access to an exercise area.

The same therapeutic protocol was used for the two experimental groups. The dogs were fed restricted amounts, corresponding to $60 \%$ of their maintenance energy requirement (NRC, 1985) calculated for their target weight, standardized as the present weight minus $15 \%$. The ration used in this experiment had $8 \%$ moisture and on dry matter basis 42\% nitrogen-free extract, $8 \%$ ether extract, 32\% crude protein, $11 \%$ crude fiber, $12 \%$ acid detergent fiber, $21 \%$ neutral detergent fiber, $7 \%$ mineral matter, $1.1 \%$ calcium, $0.9 \%$ phosphorus, $300 \mathrm{kcal} / 100 \mathrm{~g}$ and $10.7 \mathrm{~g}$ protein per $100 \mathrm{kcal}$ ME. The metabolizable energy was estimated according to the formula provided by the NRC (1985). Vitamins and minerals were added to the food at higher levels than those recommended by AAFCO (2003). The ration was produced at the Campinas Manufacturing Unit of Mogiana Alimentos S. A. (GUABI) and donated to the project.

The experimental hypocaloric diet was given free of charge to dogs of group 1 , as an incentive to the owners who were willing to participate in the program. Each owner received a measuring cup adjusted to his animal to make it easier to give the daily correct amount of food, divided into two or three meals according to their convenience. The project's team fed dogs of group 2 once a day, always at the same time.

The therapeutic protocol also recommended daily walks, that no treats or other foods are to be given during the treatment, and the dog should be fed in a different area than other dogs or cats of the same household. It was anticipated that this protocol would result in an average loss of $1.25 \%$ of the body weight per week, so dogs would reach the target weight in approximately 12 weeks.

A structured questionnaire was applied during the first appointment of Group 1. In order to obtain general information about the animals, questions 1 through 15 of questionnaire 1 (Appendix 1) were answered by all owners. This was followed by a structured dialogue on how to recognize obesity, its causes, consequences and treatment. After the information had been provided, questions 1, 2, 13, 14 and 15 of questionnaire 1 were applied again in order to evaluate the changes in the client's perception. Only the owners that wanted to carry out the weight loss treatment were asked question number 16 .

A second questionnaire (Appendix 1) was used on days 30 and 90 of the treatment. The objective of this second evaluation was to raise the client's perception in relation to the weight loss of his pet, the beneficial aspects as well as the difficulties. A periodic contact by phone was made as a way to stimulate owners. Treatment failures and the weight goals to be reached until the next appointment were discussed during the visits.

The body weight of group 1 dogs was evaluated once or twice a month, according to the owners' availability, and twice a month in group 2 . 


\section{APPENDIX 1}

\section{QUESTIONNAIRE 1}

1) Do you consider your animal as obese?

$\begin{array}{ll}\text { ( ) Yes } & \text { ( ) No }\end{array}$

2) What is the body condition of your dog, in relation to weight?
( ) Normal
( ) Low
( ) Slightly higher
( ) Much higher

3) Is your dog feed with a commercial food? ( ) Yes ( ) No

4) Is your dog fed with homemade food?

$\begin{array}{ll}\text { ( ) Yes } & \text { ( ) No }\end{array}$

5) How often is the food given?

( ) Once a day ( ) Twice a day

( ) Three times a day ( ) More than 3 times a day

6) How do you feed your dog?

( ) Leave it in the bowl

( ) Follow the label instructions

( ) Provide the food and remove it after some time if the dog does not eat all of it

7) Besides the ration or homemade food, do you usually give some other type of food to your dog (as biscuits, sweets, table or meat scraps, etc.) ?
( ) Yes
( ) No

8) Is there more than one dog or cat in the household?
( ) Yes
( ) No

9) Is the animal active in the environment where it lives? ( ) Yes

( ) No

10) Do you play with your dog in the yard or inside your home?

( ) Yes

( ) No

11) Do you walk/run with your dog?

$\begin{array}{ll}\text { ( ) Yes ( ) No } & \end{array}$

Remark: If the answer is negative, skip next question.

12) How often does your dog have some physical activity?

( ) Daily ( ) Every week ( ) Up to 3times/week

13) Do you think that obesity is harmful for the animal's health?

( ) Yes

( ) No

14) In your opinion, can an obese animal be more limited than an animal with ideal weight in relation to exercising, to be willing to play, run, be more heat tolerant etc?

$\begin{array}{ll}\text { ( ) Yes } & \text { ( ) No }\end{array}$

15) Are you willing to provide your dog with a weight loss program?
( ) Yes
( ) No

16) What are the difficulties that can eventually arise in establishing a weight loss treatment for your dog?

a) Exercising

$\begin{array}{ll}\text { ( ) Yes } & \text { ( ) No }\end{array}$

b) Cost of the hypocaloric food
( ) Yes

( ) No

c) Changes in eating habits

( ) Yes

( ) No

d) Be able to make all those involved with the animal to

follow the treatment

$\begin{array}{ll}\text { ( ) Yes ( ) No } & \end{array}$

e) Have a feeling that the animal will go hungry

$\begin{array}{ll}\text { ( ) Yes } & \text { ( ) No }\end{array}$

f) Not resist the temptation to give the animal some treats

$\begin{array}{ll}\text { ( ) Yes } & \text { ( ) No }\end{array}$

g) Think that the animal will suffer with the treatment

$\begin{array}{ll}\text { ( ) Yes ( ) No } & \end{array}$

h) Consider the animal to be too old to undergo a treatment

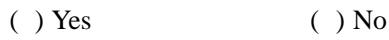

i) Think that the animal will no longer like you because you'll no longer give him the treats he enjoys so much
( ) Yes
( ) No

2. QUESTIONNAIRE 2

1) Are you and other people that interact with the dog following the treatment correctly?
( ) Yes
( ) No

2) What are the difficulties found in carrying out the treatment until now?

a) Providing physical exercises
( ) Yes
( ) No
b) Feeding frequency

( ) Yes

( ) No

c) I can't prevent myself from giving treats to my dog

( ) Yes

( ) No

d) My dog is hungry

( ) Yes

( ) No

e) Family members are not following the treatment

$\begin{array}{ll}\text { ( ) Yes } & \text { ( ) No }\end{array}$

f) My dog does not eat the diet

$\begin{array}{ll}\text { ( ) Yes ( ) No } & \end{array}$

g) My dog eats the food of other animals

$\begin{array}{ll}\text { ( ) Yes ( ) No } & \end{array}$

h) The food is adequate

( ) Yes

( ) No

3) What were the perceived benefits for the animal during the treatment?

a) Higher activity level at home
( ) Yes
( ) No

b) Improves exercise tolerance

( ) Yes ( ) No

c) Better heat tolerance

( ) Yes

( ) No

d) Improved appearance

( ) Yes

( ) No

e) Some health improvements were perceived

$\begin{array}{ll}\text { ( ) Yes } & \text { ( ) No }\end{array}$

f) Relationship between owner and dog was improved
( ) Yes
( ) No

4) Are you optimistic with the results achieved until now?
( ) Yes
( ) No

5) Are you willing to proceed with the treatment?

( ) Yes

( ) No

6) Would you recommend this weight loss program to someone who owned an obese dog?

( ) Yes

( ) No

Ciência Rural, v.35, n.6, nov-dez, 2005. 
When the weekly weight loss was more than $2 \%$ or less than $1 \%$ of the body weight, the amount of food given was adjusted by a $10 \%$ increase or decrease respectively.

At the beginning of the treatment and during the weight loss follow-up, morphometric measures were taken on the following anatomical sites: thigh circumference: the measurement was made with the dog lying on the right side, with the left hind leg extended, using a measuring tape placed on the medium point between the patella and the greater femur trochanter; pelvic and thoracic circumference: the pelvic circumference was measured in the medium point between the ilium and the last thoracic vertebra with the animal standing, also using a measuring tape. The thoracic circumference was measured in the seventh intercostal space.

With a normal $\mathrm{Z}$ distribution and 5\% significance, the method of paired comparison was used in the statistical analysis of the proportion of answers given by owners before and after the information was provided, and the answers to questionnaires 1 and 2 after 30 and 90 days. Variance Analysis was used to compare the weight loss in the two experimental groups, according to a completely randomized design and using the Student's t-test with a 5\% significance level. All the analyses were performed in the SAS statistical program (SCHLOTZHAUER \& LITTELL, 1997).

\section{RESULTS AND DISCUSSION}

The food was not refused by any of the dogs of the two experimental groups. Stools had adequate characteristics, and during the adaptation period only two dogs of Group 1 had soft stools.

The average weekly weight loss in Group 1 was $0.75 \%$, statistically lower than the value found in Group 2, 1.39\% $(\mathrm{P}<0.05)$. Although the weight loss rate of dogs with owners was lower than anticipated in the beginning of the study, this lower rate could result in higher chances of weight maintenance after the treatment (LAFLAMME \& KUHLMAN, 1995). On the other hand, the owners' motivation in maintaining the diet is related to the weight loss rate, which should not be lower than $0.5 \%$ per week (BURKHOLDER \& BAUER, 1998), the ideal being between 1 and 2\% (LAFLAMME et al., 1997). Even so, owners of dogs that did not reach the target weight during the period of the study (90 days) maintained their animals in the program up to 10 months, being diligent and committed to the program in most cases.
Other studies with animals that had owners also resulted in low weight loss rates. GENTRY (1993) reports that after 10 months of treatment none of the animals reached the estimated target weight, the average weight loss being only $60 \%$ of the expected value. In our study, the weight loss of Group 1 was also $60 \%$ of the target weight after 3 months. Working with owner cats, BUTTERWICK \& MARKWELL (1996) achieved a $0.75 \%$ weight loss rate per week, the same as found in the present study.

There are two possible explanations for the lower weight loss percentage of dogs with owners. The first would be the unwillingness of owners to follow the therapeutic protocol, providing more calories to their animals than scheduled. In Group 2, the dogs received only the specific diet and had no access to any other source of calories, the result being a weight loss rate that was almost two times larger. Another factor that could have influenced these figures are the differences between the energy requirements of dogs living in households and dogs kept in kennels. Some studies have shown that dogs in kennels have a higher rate of physical activity, which is reflected by a higher maintenance energy requirement that can be increased by as much as $20 \%$ (CENTER, 2003). However, this was not confirmed by other studies (REMILLARD \& LESCHKE, 2003).

Only two animals of Group 2 (20.2\%) needed to have the amount of food adjusted as their weight loss was not satisfactory. In Group 1, however, 88.23\% of the dogs needed this adjustment. According to LAFLAMME et al. (1997), the equations used to calculate energy requirements have limitations and there are individual variations, factors that have to be considered when a weight loss program is designed. CENTER (2003) states that calories ingestion can vary up to $50 \%$ among healthy animals of the same breed. Although these differences can reflect individual metabolic rate peculiarities, most of them are related to the level of physical activity and the temperament of each dog.

In order to estimate the maintenance caloric requirements, a constant of $132 \mathrm{kcal}$ per metabolic weight unit, proposed by the NRC (1985), was used in the present study. In the evaluation of maintenance energy requirements of dogs with owners, CONNOR et al. (2000) found a constant $105.7 \mathrm{kcal}$ per metabolic weight unit. In a review evaluating 14 experiments, REMILLARD \& LESCHKE (2003) report a constant of 120.6. The existence or not of differences between the maintenance energy requirements of household dogs and dogs maintained in kennels requires further studies. Based on the most recent experiments on the 
energy metabolism of dogs, for instance, the caloric deficit initially anticipated in this study seems to be lower than expected.

As management and diet were the same for both groups, no comparison was made between the morphometric measures of them. After the 90-day experimental period, the dogs total average weight loss was $10.48 \%$ in relation to the initial body weight. During the same period, the average reduction of the pelvic circumference was $7.48 \%$ and of the thoracic circumference was $4.48 \%$. On the other hand, the thigh measure had a $1.07 \%$ average increase in relation to the beginning of the experiment.

In dogs, fat is deposited mainly in the subcutaneous tissue of the thorax, lumbar and coccygeal regions and also as intra-abdominal fat. BURKHOLDER \& TOLL (1997) already reported that weight gain and weight loss are directly reflected on the pelvic circumference and to a lesser extent on the thoracic circumference, as was evidenced in the present study. It was possible to visualize a waist and a certain abdominal curvature on the lateral view after the animals lost weight.

In this study, the thigh circumference measurement was used to obtain a subjective evaluation of the skeletal muscle mass, as this tissue type basically forms this region. It is also used in veterinary physical therapy as a practical way to detect loss of muscle mass or progress in the post surgical treatment of fractures. The result obtained indicated an average gain of $1.07 \%$, attributed to the physical activity reported by the owners and observed in the dogs maintained in the kennels. Besides, the high protein level (32\% on dry matter basis) of the hypocaloric diet that was used probably minimized the protein catabolism resulting from the caloric restriction. The protein level of the food used in the study was $10.7 \mathrm{~g} / 1000 \mathrm{Kcal} \mathrm{ME}$, twice as high as the $5.14 \mathrm{~g} / 1000 \mathrm{Kcal}$ ME level recommended by AAFCO (2003) for dog maintenance.

Although studies based on questionnaires have been improved along the years, this tool is not used often in veterinary medicine (GINGERICH \& STROBEL, 2003). Important information, valuable for the design of programs to treat obesity, was obtained by the use of questionnaires in the present study.

Twenty-four owners answered questionnaire 1 . The answers indicated that $58.3 \%$ of the dogs were given ration plus homemade food, $8.3 \%$ were given only homemade food and the remaining received only ration. SLOTH (1992) reported a higher incidence of obesity in dogs that were fed homemade food than in dogs that were given commercial food.
EDNEY \& SMITH (1986) and KIENZLE et al. (1998), on the other hand, reported that the obesity incidence was the same in both groups. Among owners, $75 \%$ gave treats to their dogs in addition to the usual food. According to MARKWELL \& BUTTERWICK (1994), one of the most common mistakes made by owners is to give treats and biscuits to their dogs, ignoring their caloric content, and thus can lead to excessive weight.

EDNEY \& SMITH (1986) considered that the weight gain in dogs is the result of quantitative failures in the food being offered. This was observed in our study, as most owners gave their dogs more than one kind of food, but did not know how much of each item was given. Information provided by owners about the amount of food ingested by their dogs was very subjective, making it difficult to obtain an accurate answer, as reported by RUSSELL et al. (2000).

In relation to the feeding method, $50 \%$ of the owners fed their dogs while controlling the time, $33.3 \%$ fed them ad libitum and $16.7 \%$ followed the commercial food label instructions. Thus, there is very little control over the amount of food provided to the dogs, as $88.3 \%$ of the feed management relies on the ad libitum and time controlled systems. This latter system is used already anticipating leftovers and has no control over ingestion. For some animals, the ad libitum feeding and/or free access to highly palatable food is the main cause of weight gain (CENTER, 2003). Even dogs fed according to the label instructions of commercial foods can gain weight as the energy recommendations for dogs provided by Nutrient Requirement of Dogs (NRC, 1985) seems to be excessive (KIENZLE et al., 2002; CENTER, 2003).

In relation to the body condition, only $48 \%$ of the owners classified their dogs as obese (body score of 5). After the information had been provided and a picture of body condition score showed, owners were asked again about the body condition of their animal and there was no significant difference in the response rates obtained ( $p>0.05$ ). These findings are in agreement with those found by SINGH et al. (2002) in the United States, as they report that owners underestimated by 20 or $30 \%$ the excessive weight of their dogs.

In relation to the difficulties that may be found in treating obesity, $41.7 \%$ of the owners referred the cost of the therapeutic food, 33.3\% the concern that the animal would be hungry, $29.2 \%$ indicated exercising, $21.7 \%$ would find it difficult not to give any other type of food, and $16.7 \%$ believed that people of the household would not cooperate with the treatment. 
Owners pointed out that psychological difficulties would be the major limitation to weight loss programs, as they would certainly fail if the owner was not committed to the treatment (SLOTH, 1992; BURKHOLDER \& TOLL, 1997). They tend to believe that they are so fond of their dogs that rewarding them with a treat is to promote the man-animal interaction (KIENZLE et al., 1998). In our study, the dichotomy food restriction/animal welfare came next to the food cost as the major difficulties owners believed they would have in implementing the treatment for obesity.

The last question of questionnaire 1 referred to the owners' willingness to include their dogs in a weight loss program, and 96\% were willing to carry out the treatment. The high rate of compliance found in our study can be due to the supply of free food given to owners, as approximately half of them reported cost of the hypocaloric food as a limiting factor. In the Clinical Nutrition Service for Dogs and Cats of HV, the high price of a specific diet is one of the major causes of refusing to participate in and/or dropping out of the weight loss treatment

In the present study $56.67 \%$ of the owners completed the 90 -day treatment, $17 \%$ did not return, $13.33 \%$ dropped out during, and $10 \%$ had to discontinue the program because their dogs had health problems. In a study reported by GENTRY (1993), 40\% of the owners never returned and 5\% had to leave the program for health reasons. The difficulties more often reported by the answers to questionnaire 2 were exercising (walks), believing that the dogs were going hungry and not resisting the temptation of giving them some other food type, besides the food for weight loss. These actual difficulties were compared to those imagined by the owner as reported by the answers to questionnaire 1 (Table 1).

Many owners believed that there would be no difficulties in exercising their dogs. However, this was the question most often pointed out during the study. There was a significant difference $(\mathrm{p}<0.05)$ between the answers to questionnaire 1 and questionnaire 2 (30 days). The main reasons referred by owners as limiting factors for this were lack of time, health problems of the owner or the dog, and the animal's temperament. Physical exercise, however, is the most efficient way to maintain muscle mass during the weight loss process and to reduce weight faster, besides helping to maintain the ideal weight after dieting(BURKHOLDER \& TOLL, 1997).

To promote satiety, the diet had higher levels of fiber (JEWELL et al., 2000) and starch with slow assimilation, and was given several times per day. Even so, at the end of the experiment, $50 \%$ of the interviewed owners believed that their dogs were hungry. Ingestion of any other type of food provides additional calories that had not been anticipated, interfering with the weight loss. The common "food begging” behavior is interpreted as hunger sensation by the owner, who will give treats, table scraps or even commercial food to the animal. The owner should be informed that the begging behavior is positively reinforced and perpetuated every time the animal is given something after begging (NORRIS \& BEAVER, 1993).

Among the weight loss benefits perceived after 30 days of treatment, $44.4 \%$ of owners reported their dogs had a higher level of activity. This was more evident after 90 days, being perceived in $64.3 \%$ of the dogs. After 90 days of treatment, $78.6 \%$ of the owners described some kind of improvement in the animal's appearance (haircoat, esthetics and vivacity). Other health benefits were reported by $57.1 \%$ of owners including improvement or control of pseudo pregnancy, joint and locomotor problems, breathing difficulties. All owners stressed that they would recommend the weight loss program to other obese dog owners.

Table 1 - Main difficulties imagined by the owners before the treatment and actually found during the weight loss process, days 30 and 90 of the study. Jaboticabal, 2003.

\begin{tabular}{|c|c|c|c|}
\hline & Before the treatment (T0) & After 30 days treatment (T30) & After 90 days treatment (T90) \\
\hline & \multicolumn{3}{|c|}{ Answers (\%) } \\
\hline Physical activity & $28.6^{\mathrm{A}}$ & $78.6^{\mathrm{Ba}}$ & $64.3^{\mathrm{Aa}}$ \\
\hline Dog with sensation of hunger & $35.7^{\mathrm{A}}$ & $14.3^{\text {Aa }}$ & $50.0^{\mathrm{Ab}}$ \\
\hline Extra food being offered & $14.3^{\mathrm{A}}$ & $0^{\text {Aa }}$ & $14.3^{\mathrm{Aa}}$ \\
\hline
\end{tabular}

A, B - Based on the $\mathrm{Z}$ test $(\mathrm{p}<0.05)$, averages on the same line with no common capital letter are statistically different. Comparison is only valid between $\mathrm{T} 0$ and $\mathrm{T} 30$, and $\mathrm{T} 0$ and $\mathrm{T} 90$.

a, b- Based on the $\mathrm{Z}$ test $(\mathrm{p}<0.05)$, averages on the same line with no common small letter are statistically different. Comparison is only valid between T30 and T90. 
In general, obese dogs have tachypnea, exercise intolerance and are more prone to hypoxia. GENTRY (1993) reports that these effects tend to be reverted with weight loss, which was observed in the present study. Animals that loose weight become more active, alert and companionable (HAND et al., 1989), characteristics that were spontaneously reported by many owners. The excessive body weight is considered to be a risk factor for the development of osteoarthritis in man and dogs (SMITH et al., 2002). A study by IMPELLIZERI et al. (2000) found an improvement in the hip osteoarthritis of obese dogs after a $14 \%$ weight loss, achieved after 10 to 19 weeks of treatment. A lower prevalence of pseudo pregnancy reported by one owner participating in our study had already been described by LAWLER et al. (1999) in bitches under food restriction, indicating that this condition can be influenced by physiological factors related to nutrition.

\section{CONCLUSION}

The authors found that energy restriction and the food used for weight loss were effective, as the dogs of FCAV/Unesp had an adequate weight loss rate. It was also found that owners have difficulty in recognizing the obesity of their dogs and are not willing to follow the therapy protocol. Their satisfaction with the results obtained was noticeable, even in cases where the target weight loss was not achieved. The use of questionnaires was shown to an important auxiliary tool in determining the causes of canine obesity and in identifying the difficulties related to the treatment as well as owners' perception.

\section{ACKNOWLEDGEMENTS}

We thank Mogiana Alimentos S. A. (GUABI) for the financial support to carry out this study.

\section{REFERENCES}

AAFCO - ASSOCIATION OF AMERICAN FEED CONTROL OFFICIALS. Dog and cat food substantiation methods Official Publication. Ottawa, 2003. 444p.

BURKHOLDER, W.J.; BAUER, J.E. Foods and techniques for managing obesity in companion animals. Journal of the American Veterinary Medical Association, Schaumburg, v.212, n.5, p.658-662, 1998.

BURKHOLDER, W.J.; TOLL, P.W. Controle da obesidade. In: HAND, M.S. et al. Small animal clinical nutrition IV. Topeka, Kansas: Mark Morris Institute, 1997. p.1-44.

BUTTERWICK, R.F.; MARKWELL, P.J. Changes in the body composition of cats during weight reduction by controlled dietary energy restriction. Veterinary Record, v.138, p.354357, 1996.

CENTER, S. Obesity prevention. PetFood Industry, Illinois,v.45 n.1, p.12-17, 2003.

CONNOR, M. et al. Variation in maintenance energy requirements of pet dogs. In: PURINA NUTRITION FORUM, 1999, St. Louis, Missouri. Proceedings... Charlotte, North Carolina: The Gloyd, 2000. p.84.

EDNEY, A.T.B.; SMITH, P.M. Study of obesity in dogs visiting veterinary practices in the United Kingdom. Veterinary Record, London, v.118, n.14, p.391-396, 1986.

GENTRY, S.J. Results of the clinical use of a standardized weight-loss program in dogs and cats. Journal of American Animal Hospital Association, Schaumburg, v.29, n.4, p.369375, 1993.

GINGERICH, D.A.; STROBEL, J.D. Use of client- specific outcome measures to assess treatment effects in geriatric, arthritic dogs: controlled clinical evaluation of a nutraceutical. Veterinary Therapeutics, Yardley, v.4, n.1, p.56-66, 2003.

GRECO, D.S. Life is shorter, if you eat desert first: clinical implications of the purina 448 study. In: PURINA PET INSTITUTE SYMPOSIUM, 2002, St. Louis, Missouri. Proceedings... Wilmington, DE: Nestle, 2002. p.35-38.

HAND, M.S. et al. Obesity: occurrence, treatment, and prevention. Veterinary Clinics of North America: Small Animal Practice, Philadelphia, v.19, n.3, p.447474, 1989.

IMPELLIZERI, J.A. et al. Effect of weight reduction on clinical signs of lameness in dogs with hip osteoarthritis. Journal of American Veterinary Medical Association, Schaumburg, v.216, p. 1089-1091, 2000.

JEWELL, D.E. et al. Satiety reduces adiposity in dogs. Veterinary Therapeutics, Yardley, v.1, n.1, p.17-23, 2000.

KIENZLE, E. et al. A comparison of the feeding behavior and the human-animal relationship in owners of normal and obese dogs. Journal Nutrition, Bethesda, v.128, n.12, p.2779S2782S, 1998.

KIENZLE, E. et al. Calculation of gross energy in pet foods: Do we have the right values for heat of combustion? Journal Nutrition, Bethesda, v.132, n.6, p.1799S-1800S, 2002 .

LAFLAMME, D.P.; KUHLMAN, G. The effect of weight loss regime on subsequent weight maintenance in dogs. Nutrition Research, v.15, n.7, p.1019-1028, 1995.

LAFLAMME, D.P. et al. Evaluation of weight loss protocols for dogs. Journal of the American Animal Hospital Association, Schaumburg, v.33, n.3, p.253-259, 1997.

LAWLER, D.F. et al. Influence of restricted food intake on estrous cycles and pseudopregnancies in dogs. American Journal Veterinary Research, Schaumburg, v.60, n.7, p.820-825, 1999. 
LEWIS, L.D. et al. Obesity. In: LEWIS, L.D. et al. Small animal clinical nutrition III. Kansas: Mark Morris Institute, 1994. V.6, p.1-39.

MARKWELL, P.J.; BUTTERWICK, R.F. Obesity. In: WILLS, J.M.; SIMPSON, K.W. The waltham book of clinical nutrition of the dog \& cat. Oxford: Pergamon, 1994. p.131-148.

MONTEIRO, J.B.R. Curso de atualização em obesidade: do seu aparecimento ao seu controle nutricional. Viçosa: Universidade Federal de Viçosa, 1999. 78p.

NORRIS, M.P.; BEAVER, B.V. Application of behavior therapy techniques to the treatment of obesity in companion animals. Journal American Veterinary Medical Association, Schaumburg, v.202, n.5, p.728-730, 1993.

NRC. National Research Council - Nutrient requirements of dogs. Washington: National Academy, 1985 77p.

REMILLARD, R.L.; LESCHKE, R. Maintenance energy requirements of pet dogs vs. research colony dogs. In: AMERICAN ACADEMY OF VETERINARY NUTRITION (AAVN) CLINICAL NUTRITION AND RESEARCH
SYMPOSIUM, 2003, St. Louis, Missouri. Proceedings... Wilmington, DE: Nestle. 2003. p.43.

RUSSELL, K. et al. Influence of feeding regimen on body condition in the cat. Journal Small Animal Practice, London, v.41, n.1, p.12-17, 2000.

SCHLOTZHAUER, S.; LITTELL, R.C. SAS system for elementary statistical analysis. 2.ed. Cary: SAS Institute, 1997. 456p.

SINGH, R. et al. Owner perceptions of canine body condition score. Journal Veterinary Internal Medicine, Lakewood, v.16, p.362, 2002.

SLOTH, C. Practical management of obesity in dogs and cats. Journal of Small Animal Practice, London, v.33, n.4, p.178-182, 1992.

SMITH, G.K. et al. Effects of restricted feeding on onset, incidence, and severity of the hip dysplasia and osteoarthritis in dogs: Diagnostic, therapeutic and genetic ramifications. In: PURINA PET INSTITUTE SYMPOSIUM, 2002, St. Louis, Missouri. Proceedings... Wilmington, DE : Nestle, 2002. p.19-22. 